\title{
Simple Approaches to Reduce Radiation in the Electrophysiology Laboratory Replay
}

Francesco Zanon ${ }^{1}$ and lina marcantoni ${ }^{1}$

${ }^{1}$ Hospital Santa Maria della Misericordia

May 14, 2020

\section{Hosted file}

definitivo 13520 con references.docx available at https://authorea.com/users/322023/ articles/451223-simple-approaches-to-reduce-radiation-in-the-electrophysiologylaboratory-replay 